\title{
REGENERAÇÃO in vitro DE URUCUM (Bixa orellana L.) A PARTIR DE DIFERENTES TIPOS DE EXPLANTES ${ }^{1}$
}

Jane Fiuza Rodrigues Portela de Carvalho², Carlos Roberto de Carvalho² e Wagner Campos Otoni ${ }^{3}$

\begin{abstract}
RESUMO - Este trabalho teve como objetivo avaliar a regeneração in vitro de plantas de urucum (Bixa orellana L.) a partir de diferentes tipos de explantes. Para definir o meio de cultura adequado para indução de brotações, diferentes concentrações e, ou, combinações da auxina AIA e das citocininas BAP e ZEA foram testadas. As melhores respostas de regeneração para segmentos de hipocótilo, nós cotiledonares e hipocótilos invertidos foram observadas em meios suplementados de ZEA $(2,28 \mu \mathrm{M})$ e AIA $(0,30 \mu \mathrm{M}), \mathrm{ZEA}(4,56 \mu \mathrm{M})$ e ZEA $(4,56 \mu \mathrm{M})$, respectivamente. O meio de enraizamento mais eficaz foi o MS, com a metade de sua concentração salina e $5 \mu \mathrm{M}$ de AIB. Análises citológicas, realizadas antes da aclimatação, confirmaram a estabilidade cromossômica das plantas cultivadas in vitro, não sendo detectado variação com relação ao número de cromossomos metafásicos $(2 \mathrm{n}=14)$
\end{abstract}

Palavras-chave: Propagação in vitro, organogênese, urucum e cultura de tecidos.

\section{IN VITRO REGENERATION OF ANNATTO (Bixa orellana L.) FROM VARIOUS EXPLANTS}

\begin{abstract}
The present work aimed the establishment of a regeneration protocol for annatto (Bixa orellana $\mathbf{L}$.) from different juvenile explants. In order to promote shoot induction, different concentrations and/or combinations of IAA and the cytokinins BAP and ZEA were assessed. Better regeneration responses were achieved when segmented hypocotyl, cotiledonary nodes and inverted hypocotyl were cultured onto MSbased medium supplemented with ZEA (2.28 $\mu M)$ and IAA (0.30 $\mu M)$, ZEA (4.56 $\mu M)$ or ZEA (4.56 $\mu M)$, respectively. Rooting of elongated shoots displayed higher frequencies when half-strength MS medium with IBA $(5 \mu M)$ was used. No genetic variation was detected among regenerants as revealed by cytological analysis based on metaphasic chromosome countings $(2 n=14)$.
\end{abstract}

Keywords: micropropagation, organogenesis, annatto and tissue culture.

Abreviações: $\mathrm{AIA}=$ ácido 3-indolilacético; $\mathrm{AIB}=$ ácido indolilbutírico; $\mathrm{APM}=$ amiprofos-metila; $\mathrm{B} 5=$ meio de Gamborg et al. (1968); $\mathrm{BAP}=6$-benzilaminopurina; $\mathrm{GA}_{3}=$ ácido giberélico; MS0 = meio de Murashige e Skoog (1962), não suplementado com reguladores de crescimento; e ZEA= zeatina.

\footnotetext{
${ }^{1}$ Recebido em $1^{\circ} .06 .2004$ e aceito para publicação em 10.08.2005.

${ }^{2}$ Departamento de Biologia Geral da Universidade Federal de Viçosa, 36570-000 Viçosa - MG, Brasil.

${ }^{3}$ Departamento de Biologia Vegetal da Universidade Federal de Viçosa, 36570-000 Viçosa - MG, Brasil. E-mail:<ccarvalh@ ufv.br>.
} 


\section{INTRODUÇÃO}

A importância do urucum (Bixa orellana L.) devese, principalmente, à presença em suas sementes dos pigmentos bixina e norbixina (SCOTTER et al., 1998), os quais estão sendo amplamente usados como corantes naturais nas indústrias de alimentos, de laticínios, de bebidas, de tintas, de cosméticos, farmacêuticas e têxteis (MELO e LIMA, 1990; PÓVOA, 1992), em virtude da crescente proibição da utilização de aditivos sintéticos, especialmente na indústria alimentícia (PRENTICEHERNANDEZ e RUSIG, 1992).

Em face da reprodução predominantemente por polinização cruzada e da propagação realizada exclusivamente via sementes, os cultivos de urucum apresentam alta variabilidade genética, especialmente relacionada com o número de sementes por cápsula e com a cor e o teor de pigmentos contidos nos tegumentos das sementes (FALESI, 1987).

Em razão da grande variabilidade genética e por ser uma espécie perene, a propagação vegetativa constitui um método viável para a multiplicação de indivíduos geneticamente superiores, de modo a se obterem plantios clonais de altas produtividade e qualidade.

Dentre as técnicas de propagação vegetativa, a propagação in vitro de plantas tem apresentado algumas vantagens, como possibilitar maior controle sobre a sanidade do material propagado e possibilitar rápida multiplicação, em qualquer época do ano, a partir de explantes mantidos in vitro (HU e WANG, 1984; VILLALOBOS e THORPE, 1991). No entanto, ainda são poucos os relatos envolvendo a cultura in vitro de urucum (D'SOUZA e SHARON, 2001; SHA VALLI KHAN et al., 2002; PAIVA NETO et al., 2003).

O objetivo deste trabalho foi avaliar a regeneração in vitro de plantas de urucum a partir de distintos tipos de explantes. Para isso, foram testados diferentes meios de cultura para a indução de brotações e de enraizamento.

\section{MATERIAL E MÉTODOS}

\section{Desinfestação e germinação in vitro das sementes}

Plântulas axênicas de urucum foram obtidas a partir da desinfestação de sementes em álcool etílico $70 \%$ (v/v), durante 1 min e, subseqüentemente, em uma solução de hipoclorito de sódio 2,5\% (v/v), acrescida de Tween 20 a $0,1 \%$ (vv), por 20 a $25 \mathrm{~min}$. Transcorrido esse tempo, as sementes foram lavadas quatro a cinco vezes em água destilada e autoclavadas e, em seguida, foram mantidas imersas em água estéril por 24 horas, sob agitação orbital (100 rpm), a uma temperatura de $26 \pm$ $2{ }^{\circ} \mathrm{C}$. Posteriormente, as sementes foram transferidas para o meio de cultura constituído da metade da concentração dos sais básicos de MS (MURASHIGE e SKOOG, 1962), suplementado com o complexo vitamínico do meio B5, $2 \%(\mathrm{p} / \mathrm{v})$ de sacarose, $50 \mathrm{mg} \mathrm{L}^{-1}$ de mio-inositol e solidificado com ágar (Sigma, USA) 0,8\% (p/v).

\section{Tipos de explantes}

Plântulas com 14 a 18 dias de idade, contados a partir da emissão da radícula, foram utilizadas como fonte de explantes. As plântulas foram retiradas do meio de cultura e, sob condições assépticas, segmentos de hipocótilo, nós cotiledonares e hipocótilos foram removidos e repicados para diferentes meios de cultura.

\section{Meio de indução de brotações}

O meio de cultura básico utilizado para induzir regeneração de brotações a partir dos diferentes explantes foi constituído pelos sais de MS, suplementados com o complexo vitamínico B5, $100 \mathrm{mg} \mathrm{L}^{-1} \mathrm{de}$ mio-inositol, $3 \%(\mathrm{p} / \mathrm{v})$ de sacarose e $0,8 \%(\mathrm{p} / \mathrm{v})$ de ágar (Merck, Alemanha). No cultivo de hipocótilos, o meio foi solidificado com mio-Phytagel@ (Sigma, EUA) a 0,3\% (p/v).

Diferentes concentrações e, ou, combinações dos reguladores de crescimento $\mathrm{BAP}$, $\operatorname{AIAe} \mathrm{ZEA}(\mu \mathrm{M})$ foram adicionadas ao meio básico para induzir brotações a partir de segmentos de hipocótilo, resultando nos seguintes tratamentos: meio A (controle-MS0), meio B (2,22 BAP), meio C (2,22 BAP e 0,06 AIA), meio D (2,22 BAP e 0,30 AIA), meio E (2,22 BAP e 0,60 AIA), meio $\mathrm{F}$ (2,22 BAP e 6,00 AIA), meio G (2,28 ZEA), meio H (2,28 ZEA e 0,06 AIA), meio I (2,28 ZEA e 0,30 AIA), meio J (2,28 ZEA e 0,60 AIA) e meio K (2,28 ZEA e 6,00 AIA). Segmentos de hipocótilo, com cerca de 1 cm de comprimento, foram excisados e inoculados, sob condições assépticas, nos diferentes meios de cultura. Cada tratamento constou de cinco repetições, sendo inoculados oito segmentos por placa de Petri estéril de poliestireno cristal (90 x 15 mm; J. Prolab, Brasil).

Com o intuito de verificar as respostas diferenciais de regeneração a partir de segmentos de hipocótilo, estes foram divididos em cinco partes iguais (porções apical, subapical, mediana, sub-basal e basal), de 1 cm de comprimento cada, e inoculados no meio de melhor resposta morfogênica. Essa avaliação foi feita com base na frequiência de regeneração de brotações. 
Para induzir brotações a partir de nós cotiledonares, foram adicionadas ao meio básico três concentrações de BAP $(0,0 ; 2,22$; e 4,44 $\mu \mathrm{M})$ ou de ZEA $(0,0 ; 2,28$; e $4,56 \mu \mathrm{M})$. Sob condições assépticas, ápices caulinares (com aproximadamente $10 \mathrm{~mm}$ ) tiveram os cotilédones e a porção apical removidos, seguindo-se a inoculação nos diferentes meios de cultura. Cada tratamento foi composto de cinco repetições (cinco frascos de vidro de $300 \mathrm{~mL}$ ), sendo inoculados cinco segmentos por frasco.

Os meios de indução de brotações, a partir de hipocótilos, foram constituídos do meio MS básico suplementado por diferentes concentrações e, ou, combinações de ZEA e AIA ( $\mu \mathrm{M})$, perfazendo os seguintes tratamentos: meio A (controle - MS0), meio B (2,28 ZEA), meio C (2,28 ZEA e 0,30 AIA), meio D (4,56 ZEA) e meio E (4,56 ZEA e 0,30 AIA). Em câmara de fluxo laminar e sob condições assépticas, as raízes das plântulas foram submetidas a um desbaste, e o hipocótilo foi seccionado a cerca de $2 \mathrm{~mm}$ abaixo do nó cotiledonar. Em seguida, os hipocótilos foram inoculados com a polaridade invertida (hipocótilos invertidos) nos meios de indução de brotações, onde permaneceram nessa posição por, aproximadamente, 25 dias. Cada tratamento constou de 10 repetições (10 tubos de ensaio de $25 \times 150 \mathrm{~mm}$ ).

\section{Meio de alongamento das brotações}

Após a fase de indução, brotações múltiplas adventícias (inferiores a $1 \mathrm{~cm}$ de comprimento) foram excisadas de seus explantes e transferidas para um meio de alongamento composto dos sais básicos do MS, suplementado com o complexo vitamínico B5, 100 $\mathrm{mg} \mathrm{L}^{-1}$ de mio-inositol $1 \%(\mathrm{p} / \mathrm{v})$ de sacarose, $1 \%(\mathrm{p} /$ v) de glucose, $1 \%(\mathrm{p} / \mathrm{v})$ de maltose, $28,87 \mu \mathrm{M}$ de $\mathrm{GA}_{3}$, 2,28 $\mu \mathrm{M}$ de ZEA e 0,8\% (p/v) de ágar. A solução-estoque de $\mathrm{GA}_{3}$ foi esterilizada em filtros estéreis e descartáveis de 0,20 $\mu \mathrm{m}$ (Millex, Millipore) e adicionada, sob condições assépticas, ao meio de cultivo em processo de resfriamento, após a autoclavagem.

\section{Meio de enraizamento das brotações}

Os regenerantes, acima de $1 \mathrm{~cm}$ de comprimento, foram individualizados do explante original e das brotações múltiplas adventícias e, em seguida, transferidos para diferentes meios de enraizamento.
Foram testados meios compostos da metade da concentração salina do MS, suplementado com $2 \%$ $(\mathrm{p} / \mathrm{v})$ de sacarose e $50 \mathrm{mg} \mathrm{L}^{-1}$ de mio-inositol, bem como meios contendo os sais básicos do MS, suplementados com 3\% (pv) de sacarose e $100 \mathrm{mg} \mathrm{L}^{-1}$ de mio-inositol. Aos meios de ambas as concentrações salinas foram adicionados o complexo vitamínico B5, 0,3\% (p/v) de Phytagel $^{\mathrm{TM}}$ (Sigma) e AIB às concentrações de 0,$0 ; 1,25$; 2,50; e 5,0 $\mu \mathrm{M}$. Cada tratamento foi constituído de 10 repetições (10 tubos de ensaio de 25 x $150 \mathrm{~mm}$ ).

A menos que especificado, o $\mathrm{pH}$ de todos os meios foi ajustado para 5,7 $\pm 0,1$, antes da autoclavagem a $121{ }^{\circ} \mathrm{C}, 105 \mathrm{kPa}$, durante $15 \mathrm{~min}$. Igualmente, todas as culturas in vitro foram mantidas sob irradiância em torno de $36 \mu \mathrm{mol} \mathrm{m}{ }^{-2} \mathrm{~s}^{-1}$, temperatura de $26 \pm 2{ }^{\circ} \mathrm{C}$ e fotoperíodo de 16 horas (duas lâmpadas fluorescentes, Luz do Dia Especial, 20 W).

\section{Avaliação cromossômica}

Com o objetivo de confirmar-se a estabilidade cromossômica das plantas produzidas in vitro, foram amostradas 10 plantas, das quais foram retiradas quatro a cinco raízes para se proceder à análise mitótica. As raízes foram pré-tratadas com solução de APM a 12 $\mu \mathrm{M}$, por 16 horas, à temperatura de $4{ }^{\circ} \mathrm{C}$. Em seguida, foram lavadas em água corrente por $10 \mathrm{~min}$ e, em água destilada, por $5 \mathrm{~min}$. Após a lavagem, as raízes foram fixadas em solução de metanol/ácido acético (3:1) e armazenadas em freezer $\mathrm{a}-20^{\circ} \mathrm{C}$. As lâminas foram preparadas e coradas conforme as técnicas descritas por Carvalho e Saraiva (1993). Foram analisadas cerca de 10 células contendo metáfases por planta.

\section{Aclimatização das plantas}

Após o enraizamento, as plantas foram retiradas dos tubos de ensaio e as raízes, lavadas em água corrente, para a remoção do excesso de meio de cultura. Em seguida, foram acondicionadas em copos plásticos contendo água desionizada e autoclavada, envolvidos por um saco plástico e mantidos sob condições ambientes. Pequenos orifícios foram feitos no saco plástico, a cada dois dias, e após o décimo dia as plantas foram transferidas para vasos plásticos de $0,5 \mathrm{~kg}$ de capacidade, contendo substrato orgânico Plantmax ${ }^{\circledR}$, e conduzidas para salas de crescimento com nebulização intermitente, onde permaneceram por três dias. A seguir, as plantas foram levadas para a casa de vegetação.

R. Árvore, Viçosa-MG, v.29, n.6, p.887-895, 2005 


\section{Análise estatística}

Os experimentos foram instalados, seguindo-se o delineamento inteiramente casualizado. Foram aplicados testes para verificação da homogeneidade de variância e da distribuição normal dos dados. Quando apropriado, os dados experimentais foram submetidos à análise de variância (ANOVA), a 5\% de significância, sendo aplicado o teste de Duncan $(p=0,01)$ para comparação das médias.

\section{RESULTADOS E DISCUSSÃO}

\section{Efeito de meios de cultura na indução de brotações}

$\mathrm{Na}$ indução in vitro de brotações adventícias a partir de segmentos de hipocótilo, as menores médias, em todos os caracteres avaliados, foram obtidas em meio de cultura na ausência de fitorreguladores (meio A; Tabela 1), indicando a necessidade de incorporarem fitorreguladores ao meio de cultura. No meio A, observaram-se brotações muito pouco desenvolvidas, sem qualquer expansão foliar.

Os meios ZEA $(2,28 \mu \mathrm{M})$ e BAP $(2,22 \mu \mathrm{M})$ não diferiram quanto à freqüência de regeneração de brotações e comprimento das brotações (Tabela 1).
Meios acrescidos de ZEA produziram freqüências de brotações alongadas superiores às dos meios com BAP. Os meios H, I e K produziram brotações com eixo caulinar definido e boa expansão foliar (Figura 1A). Nos demais meios (incluindo K), verificou-se grande quantidade de brotações múltiplas com baixa expansão foliar (Figura 1B), havendo a necessidade de transferência dessas brotações adventícias para um meio de alongamento capaz de estimular o seu desenvolvimento, o que retarda o processo de propagação in vitro.

Por apresentar bons desempenhos com relação a todos os caracteres avaliados e necessitar de menor inclusão de AIA, a combinação 2,28 $\mu \mathrm{M}$ ZEA e 0,30 $\mu \mathrm{M}$ AIA (meio I) foi considerada a melhor, dentre as avaliadas, para a indução in vitro de brotações a partir de segmentos de hipocótilo de urucum (Tabela 1). É importante mencionar que a menor freqüência de brotações alongadas $(29,09 \%)$, apresentada no meio I, em relação a $\mathrm{H}(36,97 \%)$, foi resultante da maior quantidade de brotações formadas e do número ligeiramente superior de ramos alongados. Além disso, o número de brotações com comprimento acima de 0,5 $\mathrm{cm}$ foi superior no tratamento I, o que contribuiu para a sua indicação como melhor meio.

Tabela 1 - Freqüência de regeneração adventícia de brotações, número e comprimento das brotações e freqüência e número de brotações alongadas formadas em segmentos do hipocótilo de urucum, submetidos a diferentes combinações dos reguladores de crescimento (BAP, ZEA e AIA), após 45 dias de cultivo in vitro

Table 1 - Frequency of adventitious shoot bud regeneration, number and frequency of shoot buds on hypocotyl segments of annatto cultured under different growth regulators (BAP, ZEA and IAA) combinations, after 45 days of in vitro culture

\begin{tabular}{|c|c|c|c|c|c|c|c|}
\hline \multirow[t]{2}{*}{ Meio } & \multicolumn{3}{|c|}{$\begin{array}{c}\text { Reguladores } \\
\text { de Crescimento } \\
(\mu \mathrm{M})\end{array}$} & \multirow[t]{2}{*}{$\begin{array}{c}\text { Freqüência de } \\
\text { Regeneração de } \\
\text { Brotações (\%) }\end{array}$} & \multirow[t]{2}{*}{$\begin{array}{c}\text { Número } \\
\text { de Brotações }\end{array}$} & \multirow[t]{2}{*}{$\begin{array}{c}\text { Comprimento } \\
\text { das Brotações } \\
(\mathrm{cm})\end{array}$} & \multirow[t]{2}{*}{$\begin{array}{c}\text { Freqüência de } \\
\text { Brotações } \\
\text { Alongadas }(\%)\end{array}$} \\
\hline & BAP & ZEA & AIA & & & & \\
\hline A & 0 & 0 & 0 & $25,00 \mathrm{~d}$ & $0,32 \mathrm{c}$ & $0,13 \mathrm{c}$ & $0,00 \mathrm{f}$ \\
\hline B & 2,22 & - & 0 & 97,14 a & $2,47 \mathrm{ab}$ & $0,31 \mathrm{ab}$ & $15,40 \mathrm{bcd}$ \\
\hline $\mathrm{C}$ & 2,22 & - & 0,06 & $62,50 \mathrm{c}$ & $1,83 \mathrm{~b}$ & $0,32 \mathrm{ab}$ & $11,81 \mathrm{cde}$ \\
\hline $\mathrm{D}$ & 2,22 & - & 0,30 & $67,50 \mathrm{bc}$ & $1,50 \mathrm{~b}$ & $0,37 \mathrm{ab}$ & $12,14 \mathrm{cde}$ \\
\hline $\mathrm{E}$ & 2,22 & - & 0,60 & $82,85 \mathrm{bc}$ & $1,97 \mathrm{~b}$ & $0,35 \mathrm{ab}$ & 12,92 bcde \\
\hline $\mathrm{F}$ & 2,22 & - & 6,00 & $90,83 \mathrm{a}$ & $1,82 \mathrm{a}$ & $0,35 \mathrm{ab}$ & $6,05 \mathrm{de}$ \\
\hline G & - & 2,28 & 0 & $82,86 \mathrm{ab}$ & $1,89 \mathrm{~b}$ & $0,37 \mathrm{ab}$ & $25,92 \mathrm{ab}$ \\
\hline $\mathrm{H}$ & - & 2,28 & 0,06 & $92,26 \mathrm{a}$ & $2,01 \mathrm{~b}$ & $0,42 \mathrm{a}$ & $36,97 \mathrm{a}$ \\
\hline I & - & 2,28 & 0,30 & $100,00 \mathrm{a}$ & 3,18 a & $0,43 \mathrm{a}$ & $29,09 \mathrm{a}$ \\
\hline $\mathbf{J}$ & - & 2,28 & 0,60 & $94,28 \mathrm{a}$ & $2,46 \mathrm{ab}$ & $0,25 \mathrm{bc}$ & $23,52 \mathrm{abc}$ \\
\hline $\mathrm{K}$ & - & 2,28 & 6,00 & $100,00 \mathrm{a}$ & 3,35 a & $0,32 \mathrm{ab}$ & 33,99 a \\
\hline
\end{tabular}

Médias seguidas de pelo menos uma letra na coluna não diferem estatisticamente entre si, a $1 \%$ de probabilidade, pelo teste de Duncan.

R. Árvore, Viçosa-MG, v.29, n.6, p.887-895, 2005 

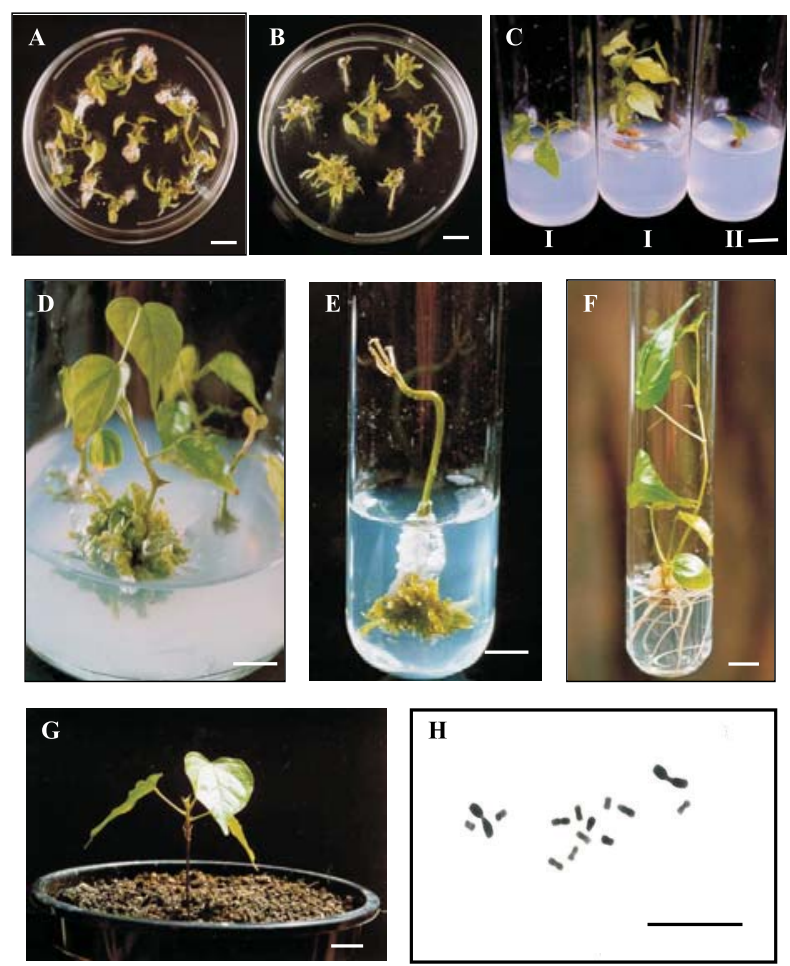

Figura 1 - Regeneração in vitro de brotações de urucum a partir de segmentos de hipocótilo cultivados em meios suplementados com ZEA $(2,28 \mu \mathrm{M})$, AIA $(0,30 \mu \mathrm{M})(\mathbf{A})$ e BAP $(2,22 \mu \mathrm{M})(\mathbf{B})$; de nós cotiledonares cultivados na presença de diversas concentrações de BAP $(\mu \mathrm{M}): 0,0(\mathbf{C I}), 2,22(\mathbf{C I I})$, 4,44 (CIII) e de 4,56 $\mu$ M de ZEA (D); e de hipocótilos em meios suplementados com 4,56 $\mu \mathrm{M}$ de ZEA. Rizogênese in vitro de brotações de urucum submetidas ao meio $1 / 2 \mathrm{MS}$ suplementado com $5 \mu \mathrm{M}$ de AIB (E). Planta aclimatizada $(\mathbf{F})($ barras $=10 \mathrm{~mm})$. Metáfase mitótica de plantas regeneradas in vitro $(\mathbf{G})$ (barra $=5 \mu \mathrm{m})$.

Figure 1 - In vitro shoot bud regeneration of annatto from hypocotyl segments cultured with ZEA $(2.28 \mu M)$ and $I A A(0.30 \mu M)(\boldsymbol{A})$ and $B A P(2.22 \mu M)(B)$; from cotiledonary nodes cultured onto different BAP concentrations $(\mu M): 0.0(\boldsymbol{C I}), 2.22(\boldsymbol{C I I})$, $4.44(\boldsymbol{C I I I})$ and $4.56 \mu \mathrm{M} Z \mathrm{ZE}(\boldsymbol{D})$; and from hypocotyls cultured with $4.56 \mu \mathrm{MZEA}$. In vitro rhizogenesis from elongated shoots of annatto cultured onto half-strength MS medium supplemented with $5 \mu M I B A(\boldsymbol{E})$. Acclimatized regenerated plant $(\boldsymbol{F})($ Bars $=10 \mathrm{~mm})$. Mitotic metaphasis from an in vitro regenerated plantlet (G) $($ Bar $=5 \mu \mathrm{m})$.
No meio I não foram observadas respostas diferenciais das regiões do hipocótilo, em relação ao número de brotações alongadas (Tabela 2). Isso contraria estudos sobre Glycine canescens, nos quais seções localizadas próximas aos cotilédones apresentaram melhor desempenho(KAMEYAe WIDHOLM, 1981). Em urucum, a freqüência de regeneração, em média, foi acima de $60 \%$, em todas as regiões do hipocótilo. A região subbasal exibiu a maior freqüência e a apical, a menor. Ao estudarem as diferentes regiões de hipocótilo de Glycine max, com relação a essa característica, Dan e Reichert (1998) verificaram que apenas a seção superior do hipocótilo (próximo aos cotilédones) demonstrouse organogênica. Em Solanum melongena L., o número máximo de brotações adventícias foi obtido a partir do segmento basal, seguido pelos segmentos sub-basal, subapical e apical (SHARMA e RAJAM, 1995).

Considerando-se o comprimento das brotações alongadas, a região sub-basal mostrou, em média, desempenho inferior aos das regiões subapical e apical, o que indica a necessidade de se transferirem as brotações formadas na região sub-basal para um meio de alongamento. A região subapical, por ter produzido a maior média para o caráter comprimento das brotações alongadas e razoável taxa de regeneração, pode ser utilizada quando se deseja acelerar o processo de propagação in vitro.

Em todos os meios testados foi observada a formação de calos de coloração esverdeada e de consistência friável nas extremidades de corte dos segmentos de hipocótilo. Calos de coloração esbranquiçada e de consistência friável, recobrindo toda a superfície dos explantes, foram encontrados somente nos meios com ZEA (Figura 1A) e nos meios com BAP acrescidos de AIA, nas concentrações de 0,60 e 6,00 $\mu \mathrm{M}$.

Independentemente da presença de fitorreguladores nos meios de cultura, em média, pelo menos uma gema axilar de cada nó cotiledonar de urucum se desenvolveu (Tabela 3). Contudo, não houve aumento no número de brotações desenvolvidas a partir das gemas axilares, ao acrescentar-se BAP ou ZEA. Nos meios suplementados com 2,22 $\mu \mathrm{M}$ de BAP, houve melhor desenvolvimento das brotações, em relação às demais concentrações testadas, apesar de essas apresentarem folhas cloróticas (Figura 1C). A concentração de $4,44 \mu \mathrm{M}$ de BAP mostrouse prejudicial, levando à formação de brotações pouco alongadas e com baixa expansão foliar, com desempenho inferior ao do controle (Tabela 3 ). 
Tabela 2 - Freqüiência de regeneração de brotações, número e comprimento das brotações alongadas formadas em diferentes regiões ao longo de segmentos do hipocótilo de urucum, submetidos ao meio MS suplementado com 2,28 $\mu \mathrm{M}$ de ZEA e $0,30 \mu \mathrm{M}$ AIA, após 45 dias de cultivo in vitro

Table 2 - Frequency of shoot regeneration, number and length of elongated shoots from explant derived from different hypocotyl regions cultured onto MS medium supplemented with $2.28 \mu \mathrm{M} Z \mathrm{ZEA}$ and $0.30 \mu \mathrm{M} \mathrm{IAA}$, after 45 days of in vitro culture

\begin{tabular}{lccc}
\hline $\begin{array}{l}\text { Região do } \\
\text { Explante }\end{array}$ & $\begin{array}{c}\text { Número de Brotações } \\
\text { Alongadas (média } \pm \text { D.P.) }\end{array}$ & $\begin{array}{c}\text { Freqüência de Regeneração } \\
\text { de Brotações }(\%) \text { (média } \pm \text { D.P.) }\end{array}$ & $\begin{array}{c}\text { Comprimento das Brotações } \\
\text { Alongadas (cm)(média } \pm \text { D.P.) }\end{array}$ \\
\hline Apical & $0,30 \pm 0,05$ & $60,0 \pm 7,45$ & $0,38 \pm 0,09$ \\
Subapical & $0,20 \pm 0,05$ & $65,0 \pm 8,61$ & $0,56 \pm 0,20$ \\
Mediana & $0,30 \pm 0,05$ & $80,0 \pm 6,97$ & $0,18 \pm 0,04$ \\
Sub-basal & $0,35 \pm 0,09$ & $90,0 \pm 4,56$ & $0,25 \pm 0,06$ \\
Basal & $0,35 \pm 0,12$ & $65,0 \pm 7,45$ & $0,15 \pm 0,05$ \\
\hline
\end{tabular}

"D.P. = desvio-padrão.

Tabela 3 - Número e comprimento médio de brotações axilares desenvolvidas a partir das gemas axilares de nós cotiledonares de urucum e freqüência desses explantes, mostrando brotações múltiplas adventícias desenvolvidas na sua base, quando submetidos a diferentes concentrações de BAP e ZEA, após 35 dias de cultivo in vitro

Table 3 -Number and mean axillary shoot length from annatto cotiledonary nodal explants, and frequency of explants displaying multiple adventitious shoot bud differentiation as affected by BAP and ZEA, after 35 days of in vitro culture

\begin{tabular}{|c|c|c|c|c|}
\hline \multirow{2}{*}{\multicolumn{2}{|c|}{$\begin{array}{l}\text { Reguladores de } \\
\text { Crescimento }(\mu \mathrm{M}) \\
\end{array}$}} & \multirow{3}{*}{$\begin{array}{c}\text { Número de Brotações } \\
\text { Axilares } \\
\text { (média } \pm \text { D.P.) }\end{array}$} & \multirow{3}{*}{$\begin{array}{c}\text { Comprimento das Brotações } \\
\text { Axilares }(\mathrm{cm}) \\
(\text { média } \pm \text { D.P. })^{1 /}\end{array}$} & \multirow{3}{*}{$\begin{array}{c}\text { Freqüência de explantes com } \\
\text { Brotações Múltiplas } \\
\text { Adventícias }(\%) \text { (média } \pm \text { D.P.) }\end{array}$} \\
\hline & & & & \\
\hline BAP & ZEA & & & \\
\hline 0 & - & $1,15 \pm 0,22$ & $0,27 \pm 0,11$ & $0,00 \pm 0,00$ \\
\hline 2,22 & - & $1,04 \pm 0,11$ & $0,75 \pm 0,20$ & $0,00 \pm 0,00$ \\
\hline 4,44 & - & $1,01 \pm 0,05$ & $0,14 \pm 0,02$ & $0,00 \pm 0,00$ \\
\hline - & 0 & $1,38 \pm 0,43$ & $0,15 \pm 0,02$ & $0,00 \pm 0,00$ \\
\hline - & 2,28 & $1,06 \pm 0,13$ & $0,74 \pm 0,16$ & $87,50 \pm 14,43$ \\
\hline - & 4,56 & $1,00 \pm 0,00$ & $0,94 \pm 0,13$ & $100,00 \pm 0,00$ \\
\hline
\end{tabular}

${ }^{1}$ D.P. $=$ desvio-padrão.

Em Gmelina arborea, o alongamento das brotações também foi dificultado a partir de gemas diferenciadas sob concentrações maiores de BAP (superiores a 2,22 $\mu \mathrm{M})$ (KANNAN e JASRAI, 1996). Em urucum, nenhuma concentração induziu a formação de brotações adventícias na base dos nós cotiledonares (Tabela 3), apesar de ter havido o desenvolvimento de calo de consistência friável na porção dos explantes em contato com o meio. Em Gmelina arborea (KANNAN e JASRAI, 1996) e em Fagus grandifolia (BARKER et al., 1997), calos na base de segmentos nodais e ápices caulinares, respectivamente, foram induzidos somente em meios de cultura suplementados com concentrações maiores de BAP (superiores a 2,22 $\mu \mathrm{M}$ ).

Nós cotiledonares cultivados com ZEA, sob concentrações crescentes, tiveram aumento no comprimento de suas brotações axilares. O desenvolvimento de uma gema axilar, cultivada em meio contendo ZEA, impediu o alongamento e a expansão foliar de outra gema de um mesmo explante (Figura 1D). Ao contrário do observado, em meios acrescidos com BAP, a ZEA não estimulou a calogênese. Contudo, favoreceu a formação de brotações adventícias múltiplas, que se desenvolveram na base dos nós cotiledonares. $\mathrm{O}$ aumento da frequiência de explantes indicando esse tipo de brotação também foi verificado ao se elevar a concentração de ZEA no meio de cultura (Tabela 3 e Figura 1D).

Ao comparar os meios suplementados com os fitorreguladores, verificou-se que o meio contendo 4,56 $\mu \mathrm{M}$ ZEA promoveu melhor desempenho. A essa concentração, as brotações axilares mostraram-se alongadas, com folhas não-cloróticas e boa expansão (Figura 1D). Além disso, em todos os explantes houve desenvolvimento de brotações adventícias múltiplas (Tabela 3). Algumas dessas brotações se alongaram no meio de regeneração, não sendo necessária a sua transferência para um meio de alongamento. 
Diferentemente do observado em segmentos de hipocótilo (Tabela 1) e em nós cotiledonares (Tabela 3), não foi verificada a indução de brotações em hipocótilos cultivados em meios de cultura sem reguladores de crescimento (Figura 2). A incorporação de 0,30 mM de AIA ao meio contendo 2,28 $\mu \mathrm{M}$ de ZEA não aumentou a freqüência de regeneração. Contudo, essa taxa foi reduzida ao se adicionar essa concentração de auxina em meios suplementados com 4,56 $\mu \mathrm{M}$ de ZEA. Dentre as concentrações avaliadas, o meio D (4,56 $\mu \mathrm{M}$ de ZEA) foi o que mostrou melhor resposta morfogênica, com base na freqüência de regeneração de brotações. A essa concentração, bem como nos demais meios acrescidos de ZEA, as porções dos hipocótilos em contato com os meios de cultura, exceto aquelas relacionadas à região de corte, desenvolveram calos de coloração esbranquiçada e de consistência friável (Figura 1E).

O primeiro sinal visível da formação de brotações adventícias, na base dos hipocótilos, foi observado nos primeiros 10 dias de cultivo, quando houve grande expansão da extremidade distal desses explantes em contato com os meios de cultura. Posteriormente, circundando toda a superfície de corte, começaram a surgir brotações. Essas se originaram diretamente a partir do tecido do explante (organogênese direta), não passando pela fase intermediária de calo. A organogênese direta também foi observada em segmentos de hipocótilo e nós cotiledonares. Em segmentos de hipocótilo foi verificado, inicialmente, um entumescimento em torno das superfícies de corte dos explantes nas primeiras duas semanas de cultivo para, em seguida, ocorrer a organogênese direta. Os calos, em geral, iniciaram-se mais tarde, após o aparecimento de gemas. A formação de calo após a organogênese, em segmentos de hipocótilo, também foi verificada em Glycine max (DAN e REICHERT, 1998). Conforme mencionado anteriormente, o processo de formação de brotações adventícias a partir de nós cotiledonares diferenciouse dos demais tipos de explantes, uma vez que não foram detectados expansão da superfície de corte e formação de calos.

Após a fase de indução, brotações múltiplas adventícias foram transferidas para um meio de alongamento. Ao final de aproximadamente 20 dias, elas atingiram cerca de $15 \mathrm{~mm}$ de comprimento e apresentaram boa expansão foliar.

\section{Efeito de meios de cultura na indução de enraizamento}

Mesmo na ausência de AIB, verificou-se a formação de raízes em explantes cultivados no meio MS (Tabela 4). Contudo, a adição do hormônio em diferentes concentrações proporcionou aumento na rizogênese. No meio $1 / 2$ MS, somente foi observado enraizamento ao adicionar-se AIB, sendo a melhor resposta obtida na concentração de $5 \mu \mathrm{M}$ dessa auxina.

Tabela 4 - Freqüência de enraizamento, número de raízes por explante enraizado e número de dias requeridos para indução de enraizamento em brotações de urucum cultivadas sob duas concentrações de sais básicos do meio MS, suplementado com diferentes níveis de AIB

Table 4 -Rooting frequencies, number of roots per explant and number of days required for rooting of annatto shoots cultured onto two MS medium salt strengths, and supplemented with different levels of IBA

\begin{tabular}{|c|c|c|c|c|}
\hline Meio & $\begin{array}{l}\text { Concentração } \\
\text { de AIB }(\mu \mathrm{M})\end{array}$ & $\begin{array}{l}\text { Freqüência de Enraizamento }(\%) \\
(\text { média } \pm \text { D.P. })^{1 / 3}\end{array}$ & $\begin{array}{l}\text { No Raízes/Explante } \\
\text { (média } \pm \text { D.P.) }\end{array}$ & $\begin{array}{c}\mathrm{N}^{\circ} \text { Dias para Indução do } \\
\text { Enraizamento(média } \pm \text { D.P.) }\end{array}$ \\
\hline \multirow[t]{4}{*}{$\overline{\mathrm{MS}^{1 /}}$} & 0 & $6,67 \pm 0,61$ & $1,00 \pm 0,00$ & $22,00 \pm 0,00$ \\
\hline & 1,25 & $20,00 \pm 2,90$ & $1,75 \pm 0,21$ & $16,50 \pm 1,93$ \\
\hline & 2,50 & $52,63 \pm 7,31$ & $3,20 \pm 0,30$ & $15,80 \pm 2,74$ \\
\hline & 5,00 & $37,50 \pm 3,25$ & $9,83 \pm 1,01$ & $14,83 \pm 2,24$ \\
\hline \multirow[t]{4}{*}{$1 / 2 \mathrm{MS}^{2 /}$} & 0 & $0,00 \pm 0,00$ & - & - \\
\hline & 1,25 & $50,00 \pm 9,09$ & $6,00 \pm 0,86$ & $18,33 \quad 4,59$ \\
\hline & 2,50 & $53,33 \pm 10,66$ & $3,38 \pm 0,27$ & $18,88 \pm 4,19$ \\
\hline & 5,00 & $66,67 \pm 8,33$ & $6,08 \pm 0,65$ & $14,33 \pm 1,91$ \\
\hline
\end{tabular}

\footnotetext{
${ }^{1 /}$ Segundo Murashige e Skoog (1962).

${ }^{2 /}$ Meio de cultura contendo a metade da concentração dos sais básicos de M.S, suplementado com $2 \%$ (p/v) de sacarose e 50 mg $1^{-1}$ de mio-inositol.

${ }^{13}$ D.P. = desvio-padrão.
} 
Em média, aumento crescente no número de raízes por explante e redução no número de dias requeridos para a rizogênese foram observados ao adicionar-se AIB sob concentrações maiores aos meios de cultivo. Isso não foi verificado nos meios $1 / 2 \mathrm{MS}$, apesar de a melhor resposta ter sido obtida sob a maior concentração testada (5 $\mu \mathrm{M}$ da auxina).

A análise simultânea dos caracteres freqüência de enraizamento, número de raízes por explante e número de dias requeridos para indução de enraizamento indicou como melhor meio para a rizogênese in vitro a partir de brotações de urucum o meio composto da metade da concentração salina de MS suplementado com 5 $\mu \mathrm{M}$ de AIB. Sob essa concentração, obtiveram-se maior número de brotações enraizadas e precocidade na formação de raízes, além de boa formação de raízes por explante (Figura 1F).

A necessidade de se incorporar AIB para a indução de rizogênese de urucum in vitro e a maior freqüência de enraizamento com suplementos de auxina a $5 \mu \mathrm{M}$, em meios 1/2 MS também foi detectada por Sha Valli Khan et al. (2002). Esses autores verificaram que a formação das raízes ocorreu diretamente na base das brotações, sem qualquer formação de calo. Contudo, no presente estudo, em todas as brotações cultivadas na presença da auxina houve a formação de calo, de consistência friável e de coloração clara, na base do explante em contato com o meio de cultura (Figura 1F). Esse calejamento foi observado, também, em alguns explantes cultivados na ausência do fitorregulador. A formação de calos tem sido relatada como uma desvantagem para a sobrevivência de plantas no campo, devido à pobre conexão vascular entre o caule e as raízes (AJITKUMAR e SEENI, 1998).

Após o processo de enraizamento, as plantas foram aclimatizadas. O índice de sobrevivência ficou em torno de $82 \%$, quando foram transferidas da condição in vitro para a de ex vitro (Figura 1G). Porcentagens semelhantes em urucum foram obtidas por D'Souza e Sharon (2001) e Sha Valli Khan et al. (2002). Contrariando Ajitkumar e Seeni (1998), esse resultado indica que os calos formados na base das brotações (Figura 2) não interferiram no desenvolvimento e sobrevivência das plantas.

Plantas regeneradas a partir de diferentes explantes não mostraram diferenças morfológicas daquelas originadas de sementes. Além disso, análises citológicas, realizadas antes da aclimatação, confirmaram a estabilidade cromossômica das plantas cultivadas in vitro (Figura 1H), não sendo detectado variação com relação ao número de cromossomos $(2 n=14)$.

R. Árvore, Viçosa-MG, v.29, n.6, p.887-895, 2005

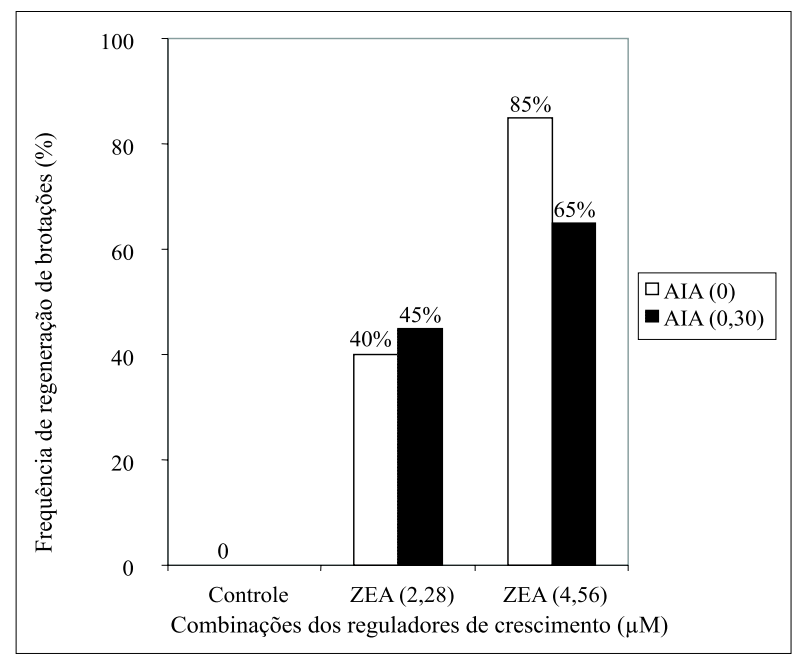

Figura 2 -Frequiência de regeneração de brotações em hipocótilos de urucum submetidos a diferentes combinações dos reguladores de crescimento ZEA e AIA, após 25 dias de cultivo in vitro. Controle - MSO (Meio de Murashige e Skoog, na ausência de reguladores de crescimento).

Figure 2 - In vitro regeneration frequencies from annatto hypocotyls as affected by ZEA and IAA concentrations, after 25 days in culture. $\boldsymbol{A}$-control - MSO (Murashige and Skoog medium, devoided of growth regulators).

\section{AGRADECIMENTOS}

Ao Conselho Nacional de Desenvolvimento Científico e Tecnológico (CNPq) e à Fundação de Amparo à Pesquisa do Estado de Minas Gerais (FAPEMIG), pelo apoio financeiro.

\section{REFERÊNCIAS BIBLIOGRÁFICAS}

AJITKUMAR D.; SEENI S. Rapid clonal multiplication through in vitro axillary shoot proliferation of Aegle marmelos (L.) Corr., a medicinal tree. Plant Cell Reports, v.17, p.422-426, 1998 .

BARKER, M.J. et al. Micropropagation of juvenile and mature american beech. Plant Cell, Tissue and Organ Culture, v.51, p.209-213, 1997.

CARVALHO, C.R.; SARAIVA, L.S. An air drying technique for maize chromosome without enzymatic maceration. Biotechnique and Histochemistry, v.68, p.142-145, 1993. 
DAN, Y.; REICHERT, N.A. Organogenic regeneration of soybean from hypocotyl explants. In Vitro Cellular Developmental Biology-Plant, v.34, n.14-21, 1998.

D'SOUZA, M.C.; SHARON, M. In vitro clonal propagation of annatto (Bixa orellana L.). In Vitro Cellular and Developmental Biology-Plant, v.37, p.168-172, 2001.

FALESI, I.C. Urucuzeiro: recomendações básicas para o seu cultivo. Belém: EMBRAPAUEPAE, 1987. 27p.

GAMBORG, O.L.; MILLER, R.A.; OJIMA, K. Nutrient requirements of suspension cultures of soybean root cells. Experimental Cell Research, v.50, p.151-158, 1968.

HU, C.Y.; WANG, P.J. Meristem, shoot tip and bud cultures. In: EVANS, D.A. (Ed.) Handbook of plant cell culture, techniques for propagation and breeding. New York: MacMillan, 1984. v.1.

KAMEYA, T.; WIDHOLM, J. Plant regeneration from hypocotyl sections of Glycine species. Plant Science Letters, v.21, p.289-294, 1981.

KANNAN, V.R.; JASRAI, Y.T. Micropropagation of Gmelina arborea. Plant Cell, Tissue and Organ Culture, v.46, p.269-271, 1969.

MELO, A.A.A.; LIMA, L.C.F. A situação do urucum no Brasil e perspectivas. In: SÃO JOSÉ, A.R.; REBOUÇAS, T.N.H. (Eds.). A cultura do urucum no Brasil. Vitória da Conquista: UESB, 1990. p 9-19.

MURASHIGE, T.; SKOOG, F. A revised medium for rapid growth and bioassays with tobacco tissue cultures. Physiologia Plantarum, v.15, p.473-497, 1962.
PAIVA NETO, V.B.; MOTA, T.R.; OTONI, W.C. Direct organogenesis from hypocotyl-derived explants of annato (Bixa orellana L.). Plant Cell, Tissue and Organ Culture, v.80, p.32-38, 2003.

PÓVOA, M.E.B. Extração do corante de urucum (Bixa orellana L.) com diversos solventes.

Revista Brasileira de Corantes

Naturais, v.1, p.153-157, 1992.

PRENTICE-HERNANDEZ, C.; RUSIG, O. Extrato de urucum (Bixa orellana L.) obtido utilizando álcool etílico como solvente. Arquivos de Biologia e Tecnologia, v.35, p.63-74, 1992.

SCOTTER, M.J. et al. Analysis of annatto (Bixa orellana) food coloring formulations. 1. Determination of coloring components and colored thermal degradation products by highperformance liquid chromatography with photodiode array detection. Journal of Agriculture Food Chemistry, v. 46, p.1031-1038, 1998.

SHA VALLI KHAN, P.S.; PRAKASH, E.; RAO, K.R. Callus induction and plantlet regeneration in Bixa orellana L., an annatto-yielding tree.

InVitro Cellular and Developmental Biology-Plant, v.38, p.186-190, 2002.

SHARMA, P.; RAJAM, M.V. Genotype, explant and position effects on organogenesis and somatic embryogenesis in eggplant (Solanum melongena L.). Journal of Experimental Botany, v.46, p.135-141, 1995.

VILLALOBOS, V.M.; THORPE, T.A.

Micropropagación: concepto, metodologia y resultados. In: ROCA, W.M.; MROGINSKI, L.A. (Eds.). Cultivo de Tejidos en la Agricultura: fundamentos y aplicaciones. Cali: CIAT, 1991. p.127-142. 